\title{
ASSOCIATION OF CLASS ATTENDANCE AND TEST PERFORMANCE WITH GRADES IN BDS FINAL PROFESSIONAL
}

Aqib Sohail ${ }^{1}$, Shakila Zaman ${ }^{2}$, Nafees ud $\operatorname{Din}^{3}$, Irfan $\mathrm{Shah}^{4}$, Aneela Amjad ${ }^{5}$, Nighat Zahid ${ }^{6}$

\section{ABSTRACT:}

\section{OBJECTIVES:}

The purpose of this study was to verify the association of class attendance percentage, and regular test marks of each taught subject in BDS final year with marks obtained in final examination.

\section{METHODOLOGY:}

Class attendance and test performance records of all participants were obtained from the college authority, and the final professional examination marks sheet issued by UHS was obtained from the college office. Potential confounders like age, gender and parents' occupation were also recorded for each student. Pearson's correlation coefficient test was applied to verify the association of class attendance and class tests marks percentage for different subjects taught with final marks. Multivariate analysis was undertaken by adjusting for confounders in the model.

\section{RESULTS:}

This study found significant correlation between each taught subject class test marks with final marks obtained in each respective subject of the final year. Class attendance of each taught subject had weak, insignificant association with final marks except in one subject i.e., Operative Dentistry.

\section{CONCLUSION:}

Class test marks are a stronger predictor of final examination marks than class attendance percentage.

KEYWORDS: Absenteeism, Continuous Assessment, Final Grades, Attendan

How to cite this article:

Sohail A, Zaman S, Din NU, Shah I, Amjad A, Zahid N. Association of Class Attendance And Test Performance with

Grades in BDS Final Professional . J Gandhara Med Dent Sci. 2021;8(4): 20-24

https://doi.org/10.37762/jgmds.8-4.251

\footnotetext{
Correspondence

${ }^{5}$ Aneela Amjad, Department of Oral Medicine, Sharif Medical \& Dental College, Lahore.

Contact: +92-300-4234903

Email: aneelaamjad.aa@gmail.com

${ }^{1}$ Professor, Department of Oral \& Maxillofacial

Surgery, Lahore Medical and Dental College, Lahore.

${ }^{2}$ Professor, Department of Public Health, University of

Health Sciences, Lahore.

${ }^{3}$ Research Associate, Bangor University, United

Kingdom.

${ }^{4}$ Professor, National University of Medical Sciences,

Rawalpindi.

${ }^{6}$ Associate Professor, Lahore Medical and Dental

College, Lahore
}

\section{INTRODUCTION:}

Student's grades in their professional examination are an established way to measure academic success. Class attendance, age, gender, socioeconomic background, internal motivation, and class academic performance have been identified as predictors of students' performance in the examination. Many factors may influence a student's final grades, but class attendance is considered the most important one, which is monitored and regulated throughout the session to improve the performance of a student in the final examination ${ }^{1,2}$. Conversely, 
several other factors including poor test scores, and poor attitude towards learning have shown a negative impact on final grades but reducing absenteeism has been shown to improve students' academic performance ${ }^{3}$. Grade point average (GPA) and scholastic aptitude test (SAT) scores prior to induction into medical school have been found to be consistent predictors of performance and have positive impact on grades along with class attendance percentage ${ }^{4}$. Regular class test results are also good predictors of students' academic performance in professional examinations. Students' performance in regular class tests during the academic year directly impacts on the final scores. A strong correlation has been reported between regular assessments and students' final examination grades. Hence, more emphasis has been placed on more frequent, regular tests rather than a few class tests at the end of the course. Additionally, performance in written and practical examinations has been positively linked with attendance in these classes during the academic year ${ }^{5}$. Furthermore, gender differences; socioeconomic background and parents' education may influence the performance as well. Male students tend to have a casual attitude toward attending regular classes but have shown a tendency to improve their performance in the final examination ${ }^{6}$. Keeping in view the importance of class attendance in determining students' final examination grades, universities have generally adopted a policy that affiliated institutions will send admission forms to sit in the professional examination only for those students who possess $75 \%$ or above class attendance percentage. Studies concluded that absenteeism had a strong negative impact on performance, but others also mentioned that mandatory attendance policies possess a small positive impact on grades ${ }^{1,2}$. This study was designed to find out the relationship of class attendance and class test performance on the final professional examination grades. Studies showing the relationship of attendance and class performance of each taught subject of BDS with final marks of different subjects are limited. The results of this study may have implications on the revisions of this policy with potentially adding a criterion of including the test performance scores along with existing mandatory requirement of attendance percentage. Hence, this study is done to know whether in our setting class attendance and performance had any contribution as the most important factor towards final grades of the students in the professional examinations.

\section{METHODOLOGY:}

This cross-sectional study was conducted at College of Dentistry, Lahore Medical and Dental College, Lahore. All the students of LMDC who appeared in the annual final UHS professional examination were included in this study after taking consent. Permission for retrieving the relevant information from college records was granted by the college office. Ethical approval was obtained from the ethics committee of the LMDC. Informed written consent was obtained from the graduates who were currently employed as interns in the college. Each participant's class attendance percentage, test performance record and marks list of all subjects of final professional examination were obtained from the college office. Class attendance is taken by roll call by the teacher in-charge and marked present on the register manually. This is then verified by counting student numbers present in the class. Traditional curriculum as approved by the UHS is followed in our institution. Classroom teaching strategy is mainly interactive format in all the taught final year subjects. Final examination format is written (MCQs and SEQs) and viva/practical. The annual test performance in each subject was calculated as the percentage marks obtained across all the tests throughout the year. Responder demographic information like age, gender and parent's occupation were also recorded. Data were collected on the predesigned printed data collection forms and entered in SPSS version 22. Association between marks obtained in the final examination for each taught subject (outcome) and class attendance and test performance percentage (predictors) were examined. Descriptive statistics depicting numbers of males and females, mean (SD) age, and percentages of class attendance, class test scores and final professional examination grades were calculated and presented in tabulated form. A Pearson's correlation coefficient was calculated for final professional exam marks obtained against student's class 
attendance and test performance. Statistical significance was set at a $P$ value of $\leq 0.05$. Multivariate analysis was conducted to determine the association of the independent outcome variable (final exam grades) with dependent predictor variables (class attendance and test scores) after controlling for confounders such as age, gender, and parent's occupation in the model.

\section{RESULTS:}

Forty-two students comprising the full class of 2014 were screened for eligibility. Four were excluded because they were detained. All the rest of the 38 agreed to participate. The mean age of the sample was $23.34 \pm 0.91$ years and ranged between 22 and 24 years. There were
34 females and 4 males with male to female ratio of 8.5:1. According to the parents' occupation of the students, $24(63.2 \%)$ fathers were businessmen, and $34(89.5 \%)$ mothers were housewives. A significant correlation was found between each taught subject class test marks with final marks obtained in the respective subject of the final year. Class attendance of each taught subject had no significant association with final grades except in one subject although has weak but significant i.e., Operative Dentistry (Prosthodontics: $\quad r=0.148, \quad p=0.382$; Orthodontics: $r=0.062, p=0.717$; Oral Surgery: $r=0.286, \quad p=0.086$; Operative Dentistry: $r=0.308, p=0.048$ ) after adjusting for the measured variables (Table 1).

Table 1: Pearson's Correlation of Attendance, Test Results with Marks in Final Examination of each taught Subject for Final Year BDS Students

\begin{tabular}{|c|c|c|c|c|c|}
\hline Subjects & $\begin{array}{c}\text { Attendance } \\
\text { Percentage } \\
\text { Mean } \pm S D\end{array}$ & $\begin{array}{c}\text { Class Test } \\
\text { Marks } \\
\text { Percentage } \\
\text { Mean } \pm S D \\
\end{array}$ & $\begin{array}{c}\text { Marks in Final } \\
\text { Examination (200) } \\
\text { Mean } \pm S D\end{array}$ & $\begin{array}{c}\text { Pearson's } \\
\text { Correlation } \\
\text { Coefficient } \\
\text { Test }\end{array}$ & $\begin{array}{l}\text { Pearson's } \\
\text { Correlation } \\
\text { Coefficient } \\
\text { Attendance }\end{array}$ \\
\hline Prosthodontics & $82 \pm 8$ & $63 \pm 14$ & $155 \pm 10$ & $\begin{array}{c}r=0.606 \\
p=<0.001\end{array}$ & $\begin{array}{l}r=0.148 \\
p=0.382\end{array}$ \\
\hline Orthodontics & $80 \pm 9$ & $66 \pm 13$ & $144 \pm 14$ & $\begin{array}{l}r=0.512 \\
p=0.001\end{array}$ & $\begin{array}{l}r=0.062 \\
p=0.717\end{array}$ \\
\hline Oral Surgery & $81 \pm 6$ & $59 \pm 6$ & $148 \pm 11$ & $\begin{array}{c}r=0.664 \\
p=<0.001\end{array}$ & $\begin{array}{l}r=0.286 \\
p=0.086\end{array}$ \\
\hline Operative Dentistry & $77 \pm 7$ & $57 \pm 12$ & $127 \pm 10$ & $\begin{array}{c}r=0.755 \\
p=<0.001\end{array}$ & $\begin{array}{l}r=0.308 \\
p=0.048\end{array}$ \\
\hline
\end{tabular}

\section{DISCUSSION:}

Our study results verified a positive significant correlation of class test performance with final professional examination. On the other hand, attendance had no statistically significant association with final marks except in one subject although it is a weak relation. Factors related to both students and teachers might influence the learning outcome. Student's regular class attendance has been related to improving achievements in educational activities $^{7-10}$. Researchers have struggled and attempted to measure the impact of absenteeism on student performance and reported that absenteeism had a negative impact on class performance and final grades $^{11-13}$. Our study findings are like those reported literature, which concluded that higher percentage of attendance is not reciprocated as good test score results ${ }^{14-16}$. All students in our study were eligible to appear in the examination and possessed a high attendance percentage, which is at or above $70 \%$, so have no linear relationship with final marks ${ }^{17}$. However, class test marks may have a linear relationship with final marks because dependent and independent variables have similarities in terms of performance grade format as marks. Secondly, we might get different results if we compare attendance percentage between groups of students who passed and failed ${ }^{5}$. In our study, class test performance had a positive relationship with final marks. Regular class tests throughout a year in a medical college may be a good predictor of academic performance in the professional examination ${ }^{18}$. Test performance provides strong prediction towards grades and such findings are in clear agreement with learning and training theories that do emphasize multiple tests and extensive 
engagement with information ${ }^{19}$.Cort right's study concluded that the impact of class attendance on examination performance was more important for female than male students ${ }^{20}$. Male students generally show a casual attitude towards class attendance and tests at the beginning of the academic session but develop seriousness before annual examination $^{6}$. Another study also highlighted that female students had good attendance and better examination performance ${ }^{5}$. Contrary to this, it has also been reported that age and gender do not play significant roles in performance ${ }^{15}$.

\section{CONCLUSION:}

The results of our study indicate that a positive correlation exists between class test marks and final marks obtained in the professional examination in our study sample. This effect appears consistent across all clinical subjects taught in the final academic year. On the other hand, class attendance does not appear to have any significant effect on the grades attained in the final professional examination.

\section{LIMITATIONS:}

Since this study is conducted on the final professional results, these results cannot be generalized on all professional examinations. Due to this limitation, similar further studies are recommended, and sample size should include all four-year undergraduate students.

CONFLICT OF INTEREST: None

FUNDING SOURCES: None

\section{REFERENCES:}

1. Gubbels J, van der Put CE, Assink M. Risk factors for school absenteeism and dropout: a meta-analytic review. J Youth Adolesc. 2019;48(9):1637-67.

2. Mohanan LK, Harichandran DT, Vijayan SM. Association of class attendance and academic performance of MBBS students in pharmacology-a retrospective cohort study. Natl J Physiol Pharm. 2017;7(10):1056.

3. Cosgrove JM, Chen YT, Castelli DM. Physical fitness, grit, school attendance, and academic performance among adolescents. BioMed Res Int. 2018;9801258:1-7.

4. Abdullah NA, Mirza MS. Predicting academic performance in undergraduate online degree programs from previous academic achievement in Pakistan. Pak J Distance Online Learn. 2019;5(2):20922.

5. Daud S, Javaid FA. Effect of class attendance of medical students' tests performance. Pak J Med Health Sci. 2012;6(2):295-7.

6. Dabaliz AA, Kaadan S, Dabbagh MM, Barakat A, Shareef MA, Al-Tannir M, et al. Predictive validity of preadmission assessments on medical student performance. Int J Med Educ. 2017;8:408

7. Sial N, Humayun R, Humayun $F$. Evaluation of factors causing absenteeism from lectures in a medical college. Khyber Med Univ J. 2018;10(3):135-9.

8. Chaudhry SH, Iqbal J. Absenteeism of medical students from subspecialty clinical rotations: a qualitative study. J Coll Physicians Surg Pak. 2019;29 (1):45-50.

9. Laird-Fick HS, Solomon DJ, Parker CJ, Wang L. Attendance, engagement and performance in a medical school curriculum: early findings from competency-based progress testing in a new medical school curriculum. Peer J. 2018;6:e5283.

10. Rafa A. Chronic Absenteeism: A Key Indicator of Student Success-Policy Analysis [Internet]. Denver: Education Commission of the States; 2017. 7 p.

11. Goothy SS, Bharath S, Paladugu S, Yamalapalli AP, Swathi M, Penmatsa GS. Effect of pre-exam absenteeism on academic performance among first year BDS students. Manipal J Nurs Health Sci. 2019;5(2):23-6.

12. Kauffman CA, Derazin M, Asmar A, Kibble JD. Relationship between classroom attendance and examination performance in a secondyear medical pathophysiology class. Adv Physiol Educ. 2018;42(4):593-8.

13. Bal-Taştan $S$, Davoudi SM, Masalimova AR, Bersanov AS, 
Kurbanov RA, Boiarchuk AV, et al. The impacts of teacher's efficacy and motivation on student's academic achievement in science education among secondary and high school students. EURASIA J Math Sci Technol Educ. 2018;14(6):2353-66.

14. Faisal R, Shinwari L, Hussain SS. Academic performance of male in comparison with female undergraduate medical students in Pharmacology examinations. J Pak Med Assoc. 2017;67(2):204-8.

15. Corbin A. Assessing differences in learning styles: age, gender and academic performance at the tertiary level in the Caribbean. Caribb Teach Scholar. 2017;7(1).

16. Madfa AA, Amran AG, Al-Sanabani FA, Alhajj MN, Al-Qudaimi NH, AlMalahy NA, et al. Prevalence of dental anxiety and fear among medical students at university of Thamar. Am J Health Res. 2015;3:5-9.

17. Giri J, Pokharel PR, Gyawali R, Bhattarai $B$. Translation and validation of modified dental anxiety scale: the Nepali version. Int Sch Res Not. 2017;5495643:1-5.

18. Masood, FM Hameed. Student's perceptions towards formative and summative assessment: a single institution study. J Islam Int Med Coll. 2016;11(1):35-40.

19. Puryer J. Dental undergraduate views of objective structured clinical examinations (OSCE): a literature review. Dent J. 2016;4(4):6.

20. Ferris HA, O' Flynn. Assesment in medical education: what are we trying to achieve?. Int J High Educ. 2015;4(2):139-44.

\section{CONTRIBUTORS}

1. Aqib Sohail - Concept \& Design; Final Approval

2. Shakila Zaman - Supervision

3. Nafees ud Din - Critical Revision

4. Irfan Shah - Data Acquisition

5. Aneela Amjad - Drafting Manuscript

6. Nighat Zahid - Data Analysis/Interpretation

LICENSE: JGMDS publishes its articles under a Creative Commons Attribution Non-Commercial Share-Alike license (CC-BY-NC-SA 4.0). COPYRIGHTS: Authors retain the rights without any restrictions to freely download, print, share and disseminate the article for any lawful purpose. It includes scholarly networks such as Research Gate, Google Scholar, LinkedIn, Academia.edu, Twitter, and other academic or professional networking sites. 